\title{
ドイモイ期のベトナム紅河デルタ農村における 経済活動と社会的ネットワーク
}

一ハイズオン省タインミエン県を事例として—

筒 井 由起乃

\section{I はじめに}

(1) 問題の所在

(2) 目的と方法

II 農村の多様性とドイモイの影響：県 レベルの分析

(1) タインミエン県の概要と村間の経 済格差

(2) 農家の農外活動

（3）出稼ぎの展開と社会経済的背景

III 経済活動の変容と農家の多角経営 :

村レベルの分析(1)
(1) ドイモイによる農家間格差の拡大

（2）農業活動の展開と農地貸借の進展

(3) 在村の農外活動と社会的ネットワ ークの展開

IV 出稼ぎの展開と社会的ネットワーク の利用：村レベルの分析(2)

（1）出稼ぎの形態と社会経済的背景

(2) 出稼ぎの種類と社会的ネットワー クの関係

（3）社会的ネットワークの展開と再生産 $\mathrm{V}$ おわりに

キーワード：農村社会, ドイモイ, 社会的ネットワーク, 多角経営, 出稼ぎ, 紅河 デルタ

I はじめに

(1)問題の所在 ベトナムの北部に広がる紅 河デル夕は, 南部のメコンデルタと並ぶベトナ ムを代表する穀倉地帯である。その農業や農村 のあり方は, ベトナムの経済・社会システムに 多大な影響を及ぼしてきた。

紅河デルタは，1平方キロメートルあたりの 人口密度が 1,000 人を超す, 極めて人口稠密な
地域である。このような人口の密集は，デル夕 開発が早くから行われたことと関係が深い。多 くの農村が, 水利, 防水, 外敵からの防禦を目 的として，デル夕内各地に形成されてきた。各 農村は，内部での社会関係を徐々に強めるとと もに，外部に対しては閉鎖性および独立性を強 化した。そうして19世紀後半以降の仏領期には, 「自律的な共同体」へと発展したのである。農 村個々の自律性は, 社会主義政権下で一時的に

1）紅河（the Red River）はホン川（the Hong River）とも呼ばれる。ホン（Hồng）はベトナム語で紅の意である。

2）メコンデルタにおけるドイモイの後の農村変容については, 原田（筒井）由起乃「加速するメコンデル夕農業の変容一 フィールドノートから一」奈良大地理 4，1998，12-28頁（共著）で述べた。

3）農村には村会や村落規範（hương ươ̂c 郷約）があり，その自律性はしばしば「王権も村の垣根まで」という諺で象徴 される。桜井由躬雄「紅河デルタにおける地域性の形成」(坪内良博編著『地域性の形成論理』京都大学学術出版会, 2000）263-300頁，などを参照。 
弱まったものの, 農村社会や農民生活において 常に重要な意味を持ちつづけた。

1986年にドイモイ (đồi mới 刷新) が始まる と，市場経済化は農村にも大きな影響を与えた。 この影響は，マクロな視点からみれば，市場経 済化による経済の急速な成長に加えて，国家経 済における農業部門の地位が相対的に低下した という産業構造の変化として理解されよう。ミ クロな視点に立てば，農業合作社（社会主義体 制下で国有農地を管理し集団農業を支えてきた）が 農地を各農家へ分配したことによって，農業の 土地生産性や労働生産性が向上したこと, その 一方で農外活動が拡大してきたことが明らかと なる。このような動向は, 1990年代以降, 特に 顕著となっている。経済発展によって農民の生 活水準は上昇した。様々な営業機会や就労機会 が増大し，経済活動は空間的にもさらに広がっ た。人とモノの動きはますます活発になってい るといえる。他方，それまで規制されていた伝
統的慣習が，ドイモイによって再評価されはじ めた。各地で，村祭をはじめとした伝統行事が 復活したり，農村の集会所であるディン（đình 亭）の補修・再建が進みつつある。このように ドイモイは，経済的側面と社会的側面のいずれ をも活性化させる方向に進んでいる。

ドイモイに関する従来の研究の多くにおいて は，市場経済化による個別農化が，経済発展あ るいは農村の社会機能の活性化と関連づけて考 察されてきた。しかしょり踏み込んでみると，

これらの研究視点は一様でない。特に個別農化 が経済発展や社会機能の活性化を引き起こした のか，あるいは経済発展が個別農化をいっそう 進め社会機能を低下させたのか，という点で異 なっている。このように諸研究の観点が互いに 大きく異なるのは，ドイモイによる市場経済の 進展が, 農村の共同体的な社会関係の活性化と 相対立するものとして受け取られてきたからで ある。加えて農村社会に対する「自律的な共同

4）社会主義政権は, 一方でその組織力を戦争や社会主義化に利用しながら, 他方では農村統治を強め, 上意下達を貫徹す るために, 従来の村を $3 \sim 6 つ$ 合わせて行政村＝社（xã）に再編し，農村の伝統的な社会機能を封じようとした。この ため農村の伝統行事は終止し, 寺社は荒廃した。(1)白石昌也『ベトナム：革命と建設のはざま』東京大学出版会, 1993, 95-99頁, (2)古田元夫『ベトナムの世界史』東京大学出版会, 1995，172頁，を参照。

5）農村における社会生活とそのベトナムにおける意義に関しては, 原田（筒井）由起乃「ベトナム紅河デル夕に扔けるム ラとムラ人」南方文化 $29 ， 2002 ， 1-20$ 頁で部分的に述べた。

6）ベトナムは中国文化圏に属するため, ベトナム語には中国語起源の単語が多い。以下，日本語による先行研究に準じ， 一部の用語については漢字を併記する。

7） ドイモイは紅河デル夕農村から興った。生産性の低さや不適切な管理体制など，それまでの集団農業の問題点が集積し たためであり，それに対して一部の農業合作社で独自に白紙請負制が導入された。古田元夫『べトナムの世界史一中華世 界から東南アジア世界へ一』東京大学出版会, 1995，172頁，を参照。

8）ドイモイ後の合作社の変容に関しては Harada（Tsutsui）Yukino, 'Rural Economy and its Impact to Farmer's Organization' (Shigeko Haruyama et. al. ed., Long Climate Change and the Environment Change of the Lower Red River Delta, 2001), pp.100-111で述べた。

9）隣国ラオスにおいて同様な農外活動の進展を地理学で扱った研究として，横山智「農外活動の導入に伴うラオス山村の 生業構造変化一ウドムサイ県ポンサワン村を事例として一」, 人文地理53-4，2001，1-20頁，がある。

10）これと対になる動きとして，実質的に行政サービスを提供する村に対して，政府財源を期待するのではなく，村独自で 財源を確保するよう促す，「民主化」政策が浸透している。岩井美佐紀「ドイモイ以後の社会的変化の一段面一ベトナム に扔ける「親農村」建設の模索一」(田中忠治先生退官記念論文集刊行委員会編『地域学を求めて一田中忠治先生退官記 念論文集一』田中忠治先生退官記念論文集刊行委員会, 1994)，293-308頁，などを参照。

11) Kerkvliet, B. J. T, ed., Vietnam's Rural Transformation, Institute of Southeast Asian Studies, 1995.

12) Le, Trong Cuc, ed., Agroecosystems of the Midlands of Northern Vietnam: A Report on a Preliminary Human Ecology Field Study of Three Districts in Vinh Phu Province, East-West Center, 1990.

13）これに関連して，スコット（1976）のモラル・エコノミー論とポプキン（1979）のポリティカル・エコノミー論がある。 両論はいずれも仏領期のベトナム農村を対象としながら, 社会の基本となる農民の行動原理について, 前者では社会的な 合意に基づいた生存倫理（subsistence ethic）の維持を強調し，後者では行動原理に内在する合理性を強調している点で 大きく異なる。(1) Scott, J. C., The Moral Economy of the Peasant: Rebellion and Subsistence in Southeast Asia, Yale University Press, 1976, (2) Popkin, S., The Rational Peasant: The Political Economy of Rural Society in Vietnam, University of California Press, 1979. 
体」という視点が, 紅河デルタ研究において伝 統的に重視されてきたこととも関わっていよう。

フランスの地理学者 P.グールー（1936）が, 紅河デル夕農村をはじめて研究の组上に載せ, この社会を「自律的な共同体 (une communaute autonome)」と特色づけた。グールーに代表さ れる仏領期の研究は，植民地宗主国側からみた という偏りはあるものの, 当時の紅河デル夕農 村の実態を明らかにし, その後の紅河デルタ農 村の研究方向を決定づけた点で意義がある。

仏領期以降の紅河デルタ農村への関心は, 「ベトナムがフランスやアメリカとの戦いで, なぜ健闘しえるのか」と、「いかにして社会主 義化が進展するのか」の 2 点に集中した。これ らの説明要因としても, 農村の伝統的な自律性 や集団理念, 組織力があげられた。 しかし北べ トナムが1945年に独立した後，ドイモイ政策開 始までの約40年間は農村調査が困難であった。 そのため, 諸研究は新たなフィールドデータに 基づかないままに，仏領期の研究成果や，それ 以前の漢籍史料に依拠して進めざるをえなかっ た。このような研究環境のもとで, 仏領期農村 は「伝統的農村」と位置づけられるようになり， 自律的という農村観がステレオタイプ化されて いった。一方, アジア的生産様式論を枠組みと した農村史研究が進められ, 紅河デル夕農村の 自律性は18・19世紀に高まったとする，発達段 階論的な見方も定着した。
これに対して桜井（1987）は, 従来のベトナ ム農村研究にみられる農村観を観念的で静態的 であると批判した。彼は史的展開を踏まえ，農 村を動態的に捉えるべきであると主張し，漢籍 史料に基ついて農村の形成過程を明らかにした。 筆者は, 桜井の指摘に加えて, 以下の 2 点が 重要であると考える。すなわち第一に, 総体と しての農村ないし農村社会を特徴づけること, 第二に農村社会の内部に立ち入って，農民が具 体的に社会や経済を構築してゆく過程を解明す ること，である。したがって，研究の視点を農 村内の個人や世帯のレベルにまで向ける必要が 生じる。

ドイモイは，「できる者から発展する」とい う考え方を基本方針としている。そのため，個 人の資質や才覚が所得拡大の鍵となる。つまり 個人が資本や能力, 情報, 人的つながりなどを いかにうまく獲得し，活用できるかが重要なの である。この点からも，農村研究において個人 的な社会関係がどのように形成され, 維持・再 生産されてゆくのかを明らかにする視点が必要 であるといえよう。本稿ではこれを社会的ネッ トワークという概念で捉えることにする。ここ でいう社会的ネットワークとは, 地縁・血縁を 基盤としつつ, これらの既存の関係を超えて, 就学時代の同級生や職場の同僚といった個人の 社会的経歷の過程で形成される諸個人間の関係 を意味する。匿名でない顔見知りの関係でもあ

14) Gourou, P., Les Peasans du Delta Tonkinois, Paris Les Edition D' art et D' histoire, 1936, pp.264-271. グールーは 他に，農村内で集団形成の志向があること，世間が私生活を支配すること，共同体的連帯が強いこと，郷紳の寊頭支配， も特徵としてあげている。

15）他に, Ory P., Commune Annamite au Tonkin, Augustin Challamel, 1894なども，農村の自律性を強調している。

16）吉沢南『個と共同性：アジアの社会主義』東京大学出版会，1987，などを参照。

17) (1) Nguyễn Hồng Phong, Xã thôn Việt Nam (ベトナムの村社), Nhà xuất bản văn sừ địa, 1959, (2) Viện sử học, Nong thon Việt Nam trong lịch sủ tập I (歴史上のベトナム農村第 1 巻), Nhà xuất bản khoa học xã hội, 1977, (3) Viện sử học, Nông thôn Việt Nam trong lịch sù tập II (歴史上のベトナム農村第 2 巻), Nhà xuất bản khoa học xã hội, 1977,などを参照。

18）桜井由躬雄『ベトナム村落の形成一村落共有田＝コンディエン制の史的展開一』創文社，1987。

19）社会学や人類学では, 社会システムを構成する諸要素間の関係を意味し, 特に家族関係をはじめとした諸個人間の関係 に重点が置かれている。Wasserman, S., Faust, K., Social Network Analysis: Methods and Applications, Cambridge University Press, 1994. 
る。なお最近では，ハノイ近郊における農外活 動の進展に伴う農村社会の変容や，ハノイにお ける出稼ぎ集団の展開など，社会的側面と経済 的側面を関連づけた実証研究もみられるように なった。本稿はこれらの諸研究と近い立場にあ るが，社会的側面を「農村の自律性」ではなく， 農村の構成要素である「個人の社会的ネットワ ーク」によって捉えている点で異なっている。

（2）目的と方法 本稿の目的は, 紅河デル夕 農村を対象として，旧来の「自律的な共同体」 という枠組みのなかで対立的に捉えられてきた， 社会的側面と経済的側面が相互に連動すること を，その動態と変容が著しいドイモイ期の農村 の分析を通して実証することである。そのため に本稿は，社会的側面の基盤となっている諸個 人の社会的ネットワークと, 個人・世帯の経済 活動の関連に焦点をあてて考察していく。

分析方法としては，現状を把握するための定 量的デー夕と変容過程を把握するための定性的 デー夕を併用し，さらにこれを複数の地域レベ ルで考察する。そうすることで, 紅河デル夕農 村の特徵を動態的かつ重層的に抽出できると考 えたからである。定量的デー夕としては，公式 統計と並んで，上述した「自律的共同体」に相 当するトン（thon 村，以下村と称す）レベルの資 料も併用した。村は現在, 正式な行政単位では ないため, 資料は収集されても統一的に保存 · 公表されることがない。そこで筆者は独自にア ンケート調査を実施した。定性的デー夕は, 県 （日本の郡に相当）と行政村であるサー（xa 社, 以下社と称す）の人民委員会幹部，村長，およ び個人に対する聞き取り調査によって得たもの
である。地域レベルについては，中央一省一県 一社一村の 5 級の行政単位のうち，以下に述べ る理由で, 県 (対象は社) と村（対象は個人 . 世帯）を選択した。

これまでの紅河デル夕農村研究においては, デル夕全域あるいは省というマクロスケールか, 村というミクロスケールに二極化する傾向があ る。しかし紅河デル夕農村の特徵を理解するた めには，県というメソスケールでの分析が不可 欠である，と筆者は考える。というのも，特に ドイモイ期の今日では，県級の中規模な中心地 への近接性やドイモイ以前からの農外就労業種 の存否によって, 各農村社会における対応が異 なっているからである。

またこれまでの研究では，マクロスケールで は統計資料やサンプリングデータを用いるのに 対し，ミクロスケールでは精徵な聞き取り調査 にのみ依拠するというように，分析手法にも乘 離がみられる。そのために，同じ紅河デル夕農 村を扱いながら，その理解に整合性を欠いてい る。この問題を解決するために，筆者は1998年 から2001年にかけて，ハイズオン省タインミエ ン県 (huyện Thanh Miện tỉnh Hải Dương) の全 18社に扔いて農村調査を実施した。本稿の記述 は特に明記しないかぎりこれらに依拠している。 ベトナムでは，1990年代半ばまで外国人が農村 に立ち入ることすら制限されていた。このよう な状況は近年改善されつつあるものの, 調査許 可や資料閲覧許可の申請はなお困難である。さ らに行政資料や統計資料は入手困難であり, 社 会主義化時代に家譜などの地方文書が消失した など，農村以外での資料収集も難しい。ことに

20）岩井美佐紀「ベトナム北部農村における社会変容と女性労働一バックニン省チャンリエット村の事例から一」東南アジ ア研究36-4，1999，525-545頁。

21) DiGregorio, M. R., Urban Harvest: Recycling as a Peasant Industry in Northern Vietnam, East West Center, 1996.

22）県には他に県庁所在地であるタインミエン町があるが，本稿では農村を対象としているため，これを分析対象からはず した。

23）購入・閲覧可能な資料は限られている。それ以外は県や社，村に閲覧を直接依頼することになるが，却下される場合も 多い。例えば全国規模の省別統計では1990年代後半以降分は市販されているため入手可能であるが, 社別のセンサスは 1995年実施のものを除き，一般には公表されていない。また人文社会科学系の調查は特に制限が多い。 
本稿で対象とするような村レベルの統計資料は, 上述したようにほとんど公表されない。したが って本稿で用いるデー夕は，このようなデータ 収集の困難性を埋める役割を有しており，資料 的に価值があると思われる。

以下，まずII章ではドイモイの経緯を概観し， 県レベルにおける農村の社会的・経済的な多様 性とその要因について検証する。これらを踏ま えたうえで，つづく章と $\mathrm{IV}$ 章では村レベルに おける個別の経済活動と社会的ネットワークと の関連を明らかにしていく。章では収入の分 析を通して農家経済の特徵と傾向を述べ（1 節)，各農家の農業活動の展開を主に農地の異 動と社会的ネットワークとの関係から示し（2 節), また農外活動の展開と社会的ネットワー クとの関連についても述べる（3 節)。IV 章で は農外活動の中でも，特に社会的ネットワーク と関連の深い出稼ぎを取り上げて，個々の社会 経済的背景が出稼ぎ形態に影響を及ぼしている こと (1 節)，出稼ぎの空間的展開に社会的ネ ットワークが関与していること（2 節），さら にはそれが出稼ぎ集団の形成という形で発展的 に応用される過程（3 節）を示す。

\section{II 農村の多様性とドイモイの影響：県レベル の分析}

(1)タインミエン県の概要と村間の経済格差 本稿の研究対象地は，八ノイから南東約 $65 \mathrm{~km}$ に位置するハイズオン省タインミエン県 である(第 1 図)。大規模な商工業はみられず， 経済的には農業が中心である。県の年間総生産 額のうち，農業部門が約 $60 \%$ を占めており， 県人口 13 万 $(2001$ 年現在 $)$ のち，農家人口が 90\%を占めている。したがって，農業を基盤と

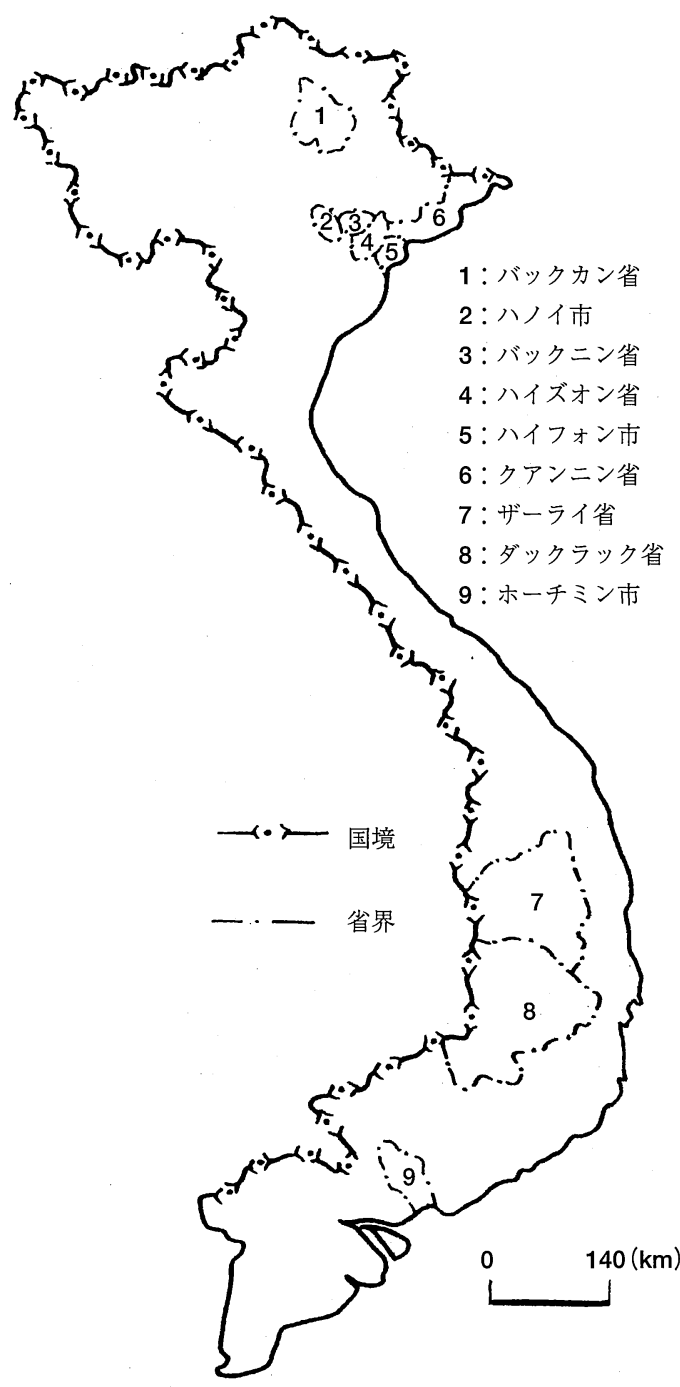

第1図 研究対象地

Figure 1. Study area

した旧来の農村社会のあり方が継承されている と示唆されよう。

さて既に述べたように，ドイモイは農村にも 市場経済を導入し，それまでの集団農業を個別 農業へ転換させた。農民は土地使用権を取得し, 農産物の生産や販売を自由に行えるようになっ

\footnotetext{
24）本稿で対象とするのは家族ではなく世帯である。事例村においては 9 割以上が農家世帯であり，アンケートの対象も農 家世帯である。以下，単位を指す以外は，農家という用語を用いることとする。

25） ベトナムでは土地は全人民の所有であるため，土地分配といっても，実際は土地使用権の分配である。しかしこの使用 権は，期限が20〜 50年と長期に亘り譲渡や相続なども認められていることから，占有ともいわれる。
} 


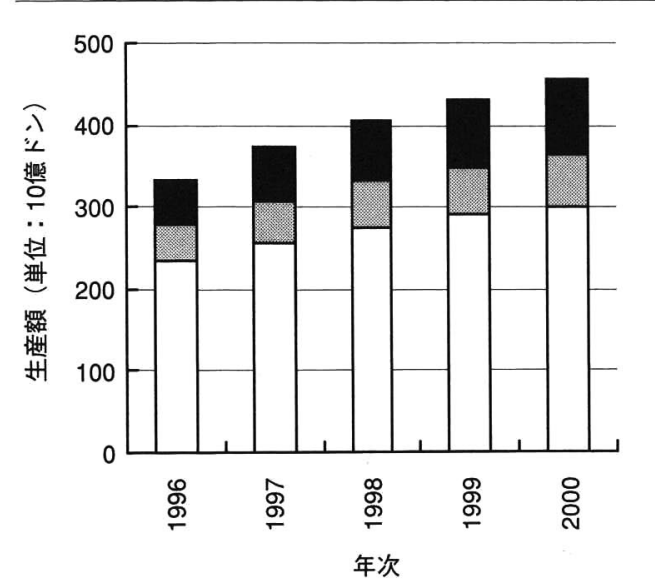

ロ農業ロエ業・建設ロサービス

第2図 タインミエン県における総生産額の推移

Figure 2. Change in gross product in Thanh Mien district

タインミエン県人民委員会資料により作成。

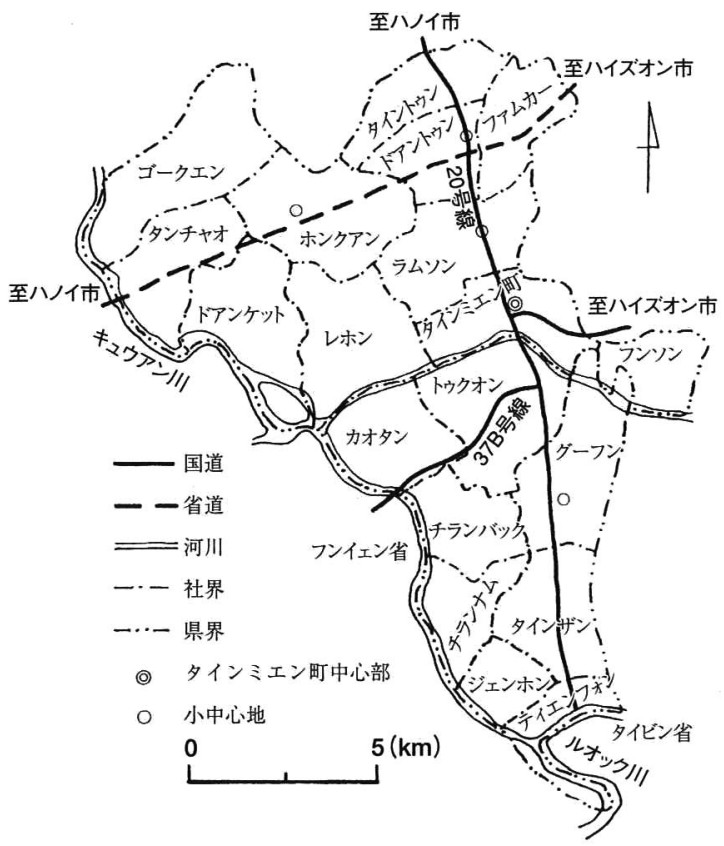

第3図 タインミエン県概略図

Figure 3. Location of Thanh Mien district

たため, 生産意欲を増長させ,ささらにその意欲 を家内手工業や小売業, 行商, 出稼ぎといった
農外活動へも向けるようになった。 ドイモイに よる経済成長と経済構造の変化は, 県の生産額 の推移にも表れている。すなわち第 2 図に示し たように，1996～2000年間の年平均成長率は8 $\%$ と高い一方で，部門別にみると農業部門 6.7 \%に対し，工業・建設部門 $9.4 \%$, サービス部 門13.4\%と，農業部門は相対的に低下した。

ドイモイの展開は，かつて「自律的な共同 体」と呼ばれた村ごとに多様である。同県は県 都のタインミエン町と18の社から成るが（第 3 図), これらの町・社の下にはそれぞれ $3 \sim 10$ の村があり，県全体では計89村となる。

各村におけるドイモイの展開の違いを，1人 当り平均年収で比較してみよう。各村長への聞 き取りによると，平均年収には200万ドン（ゴ ークエン社ファムタン村) 〜 400万ドン (ドアント ウン社ドン村）と 2 倍の格差がある。収入が少 ない村は，1 人あたり農地面積が少ない県南の 3 社（ジエンホン，タインザン, ティエンフォン） と, 県内で最もインフラ整備が遅れているゴー クエン社に集中する。他方, 収入が多い村は幹 線道路沿いに位置しており，サービス業などの 農外就労が多い傾向がある。なかでもトゥオン (ドアントゥン社), チュオン (ラムソン社), ラゴ アイ (グーフン社)，サー (ホンクアン社）の 4 村 は, タインミエン町に次ぐ県経済の拠点として, 同町と各村を結ぶ物流の中継地点となっている。

このように，ドイモイの展開には各村の農家 の経営規模や, 交通の利便性, インフラ整備と いった諸条件が関わっている。これらが農家の 収入，特に現金収入源として重要な農外収入を 規定するからである。

（2）農家の農外活動 上述したような物流の 中継地点を除くと, 農外活動は農家の副業とし

26）特に移動の自由が認められた1993年以降，この傾向が強くなっている。

27）ドン (đồng) はベトナムの通貨であり, 調査実施時の 2001 年には 1 万ドンが約 125 円であった。

28）タインミエン町と 4 つの小中心地では飲食店, カラオケ店, 各種代理店, 雑貨屋, ガソリンスタンド, 写真屋, コピー 屋など商圈が広く収益性が高い業種が展開し，農業との兼業から本業化する例もみられる。 
て行われている。製品の販売先と活動場所に着 目すると, 副業は, (1)村内副業, (2)特産品製造 業, (3)村外副業 (公設市場での販売, 行商, 出稼 ぎ)，の 3 種に区分することができる。以下， これらの展開についてみていこう。

(1)の村内副業では，基本的な生活必需品を村 内で生産・販売する。米麺, 酒, 豆腐などの食 品加工は, ほぼ全ての村でみられ, 耕うん, 収 穫, 脱穀, 精米などの農業生産関連サービスや, 木工，建設，仕立て，運搬といった業種も多く の村でみられる。これらの営業単位は, 一般に 小規模であり，しかも農業との兼業という形で 行われるか農閑期にのみ行われる。これは, 農 民が上述した職種から十分かつ安定的な収入を 得られないためである。たとえば食品加工では 需要は恒常的であるが, 利益が少ない。一方で 農業生産関連サービス, 仕立て, 建設などのそ の他の職種では, 利益は多いが需要は少なく, なおかつ季節に左右される。消費者の大半は近 隣の住人であり, 主に「紹介」や「ロコミ」に よって購入先を選択する。経営者の側にも, 自 らの人脈を利用して積極的に顧客拡大を図る者 もいる。また仕立てや木工のように技術や資本 が必要とされる業種や, 耕うんや運搬のように 高価な機械や自動車を使用するサービスでは, 村をこえて大規模化，本業化する例も出現して いる。この動向は今後の展開における一つの方 向性を示していよう。

(2)の特産品製造業は，その多くが仏領期以前 の伝統工芸に由来するものであり, 特定の村が
中心となって産地を形成している。伝統工芸と いっても, 生産物の品目や生産量は市場のニー ズに影響されている。より有利であると判断さ れれば, 販路や, 生産物の原材料, 生産物の品 目が変わることもある。たとえばグーフン社ク チー村では, かつて村の特産品であったジュー トの加工技術を活かして，ハイフォン市などで 収集した肥料や農薬をつめるビニール袋を，運 搬用のロープに再生加工している。ドアントゥ ン社ドン村では，かつて行われていた養蚕業は 収益性が悪いため, ライチの果実の乾燥加工業 に転換した。ここで強調したいのは，こうした 変化は個人・世帯レベルの選択によるものでは あるが，特定の村のみで進行する点である。す なわち特産品製造業では，原料の仕入れ元や製 品の販売先が村外であり，通常，数人の仲買人 が一括して原料を購入し，製品を販売する。し たがって，製造業に参入することができるのは， 仲買人との間で直接あるいは間接に社会関係を 持つ者に限られる。この仲買人を核としたネッ トワークは，主として社会関係が強く結ばれる 村内に限定されるため, 結果的に村の選択とし て表れるのである。

(3)の村外副業のうち, 出稼ぎは後の議論と関 わるので次節で取り上げることとし，公設市場 での副業についてみていこう。県内 18 社のうち 12社（ただしラムソン社は不明）に社人民委員会 が管理する公設市場があり(第 1 表)，衣類や 日用雑貨, 生鮮食品などが売買されている。規 模の大きな市場があるのはタインミエン町, ド

29）たとえば，豆腐製造や酒造では，製品自体は月に日本円で千円程度と利益が少ない。むしろ製造過程で出るオカラや酒 粕を利用して豚を肥育し，利益を上げている。

30）農業生産サービス関連の副業は農業暦に左右され，仕立て業，木工業はテト（旧正月）前に需要が増える。また建設は 工事に適する乾季（10～1月）に集中する。

31）なかには規模を拡大し，親族や知人10人を農閑期あるいは常時雇用する成功例もある。

32）紅河デル夕は人口稠密で余剩労働力が多かったため, 伝統的に農村工芸や出稼ぎが行われた（前揭14）, pp.448-538）。 農村工芸は現在も盛んで，ハノイ近郊のバッチャン村（陶器）などの，輸出も行う著名な工芸村もある。しかしタインミ エン県では，大規模な産地形成にはいたっていない。

33）人民委員会は，市場出店料として，月あたり $500 〜 2,000$ ドンを徵収する。市場の外には露天（人民委員会管理外）も立 つ。こうした公設市場のほかに，村では主に野菜や魚，肉などを扱う露天市（早朝，あるいは午前のみ開設）がある場合 も多い。 
第1表 タインミエン県各社における公設市場

Table 1. Public market in each commune of Thanh Mien district

（2000年現在）

\begin{tabular}{|c|c|c|c|}
\hline 社 & 数 & 市場名 & 市日 \\
\hline タイントゥン & 1 & チュア & 奇数日 \\
\hline ドアントゥン & 1 & トン & 偶数日 \\
\hline ファムカー & 1 & ド & $1,3,5 \cdots$ \\
\hline ホンクアン & 1 & サー & 奇数日 \\
\hline ゴークエン & 1 & ダン & $2,5,7,0 \cdots$ \\
\hline タンチャオ & 1 & オー & 毎日 \\
\hline ドアンケット & 1 & トゥサー & 毎日 \\
\hline レホン & 0 & & \\
\hline フンソン & 0 & & \\
\hline トゥクオン & 2 & $\begin{array}{c}\text { ザーコックアン } \\
\text { コアイ }\end{array}$ & 毎日 \\
\hline カオタン & 0 & & \\
\hline チランバック & 1 & フオンケー & 毎日 \\
\hline チランナム & 0 & & \\
\hline グーフン & 1 & ラゴアイ & 毎日 \\
\hline タインザン & 1 & タインザン & 毎日 \\
\hline ジエンホン & 0 & & \\
\hline ティエンフォン & 2 & バーハンチャイ & 毎日 \\
\hline
\end{tabular}

各社人民委員会への聞き取り調查により作成。 ラムソン社は不明。市日は院暦である。

アントゥン社, トゥクオン社, ティエンフォン 社である。市場がない 5 社, フンソン, レホン カオタン，チランナム，ジエンホンはいずれも， 上述した市場の規模が大きい町社に隣接してお り,これらの商圈に含まれる。近隣からくる出 店者は多くの場合，農業と兼業しており，主に 生鮮食料品を販売する。他方, 社外からの出店 者は全体の 20 ～50\%に及び，衣類や雑貨などの 買回り品を扱う。買物客は, 馴染みの店で生鮮 品を求め, いくつかの店で值段や品質を比較し てから買回り品を購入する場合が多い。市場で は，求める商品の值段を，相場を踏まえたうえ で交渉をする必要があるからである。市日は,
毎日催される場合と定期的に催される場合が 半々である。なかでも定期市の開催には，でき るだけ市日の重複を避けるという，伝統的な地 域間の調整の影響がみられる。たとえば，タイ ントゥン, ドアントゥン, ホンクアンの 3 社で は, 出店数 300 と規模の大きいドアントゥン社 が偶数日，これに隣接する2社が奇数日に開催 するじ，ファムカー社とゴークエン社ではそれ ぞれ $1 ， 3 ， 5$ の付く日，2，5，7，0の付 く日に開催する。このような地域間の調整は, 定期市が集中する県北部でみられる。

(3)出稼ざの展開と社会経済的背景 農家の 副業のなかでも，ドイモイ後は，特に出稼ぎが 活発となっている。出稼ぎは県内のほぼ全ての 村で行われており，その種類は以下の 6 つに大 別できる。すなわち，(1)近隣建設労働（県内） (2)遠方建設労働，(3)都市日雇い労働，(4)炭鉱労 働（クアンニン省ホンガイ炭田），(5)都市雇用労働， (6)農業労働（中部のダックラック省など），である。 (1)～(4)は農閑期の出稼ぎであり，期間は 3 ケ月 から 6 ケ月と比較的短い。それに対して(5)，(6) は年間を通しての長期間の出稼ぎである。

他の副業と同様に, 出稼ぎも村によって多様 である。これは第 2 表に示したように，社間の 差異としても表れている。たとえば，ゴークエ ン社ではクアンニン省での炭鉱労働が支配的で あるし，フンソン社では $1,000 \mathrm{~km}$ 以上離れたべ トナム中部や南部への出稼ぎが多い。こうした 差異が生じるのは，出稼ぎ先で初期支援を期待 できるかどうかや，出稼ぎ者の技術程度，通勤 可能な圈内での農外就労機会の存否といった, 個々の出稼ぎ者を取り巻く社会的，経済的な背 景が，社内ではある程度共有されるためである と考えられる。

34） ホンクアン社のサー市場の出店数は70, タイントゥン社のチュア市場の出店数は不明。なおドアントゥン社のトン市場 には社会主義化が本格化する1954年頃まで水牛市場があり，県でも有数の市として賬わっていた。

35）都市雇用労働は季節的な工場雇用や運転手などであり，日雇い労働よりも雇用が安定している一方で労㗢者の技術力が 求められる。 
第 2表 タインミエン県における社別出稼ぎ状況

Table 2. Migrant labor in each commune of Thanh Mien district

（2000年現在）

\begin{tabular}{|c|c|c|c|c|}
\hline 社 & 人口 & 出稼ぎ者概数 ${ }^{*}$ & 代表的な職種 & 代表的な行き先 \\
\hline タイントゥン & 5,516 & $200 \quad(4 \%)$ & 建設、農業 & 南部、国内各地 \\
\hline ドアントゥン & 7,321 & $600 \quad(8 \%)$ & 訪問販売, 行商 & 国内各地 \\
\hline ファムカー & 7,059 & $800(11 \%)$ & 炭鉱 & クアンニン \\
\hline ラムソン & 6,514 & $100 \quad(2 \%)$ & 建設、木工 & 北部都市 \\
\hline ホンクアン & 8,203 & $1,000(12 \%)$ & 建設、炭鉱、農業 & ハノイ, クアンニン, 中南部 \\
\hline ゴークエン & 8,163 & $400 \quad(5 \%)$ & 炭鉱、農業 & クアンニン, 南部 \\
\hline タンチャオ & 7,256 & $250 \quad(3 \%)$ & 賃労働 & 南部 \\
\hline ドアンケット & 7,137 & $1,000(14 \%)$ & 㑯労働 & 南部, クアンニン \\
\hline レホン & 7,065 & $800(11 \%)$ & 建設 & 北部都市, 南部 \\
\hline フンソン & 3,309 & $370(11 \%)$ & 建設 & ホーチミン, ハノイ, ハイズオン \\
\hline トゥクオン & 10,197 & $850 \quad(8 \%)$ & 建設 & 北部都市, 南部 \\
\hline カオタン & 5,346 & $600(11 \%)$ & 建設、炭鉱、農業 & ハノイ, クアンニン, 中南部 \\
\hline チランバック & 7,627 & $2,000(26 \%)$ & 建設、炭鉱、農業 & ハノイ, クアンニン, 中南部 \\
\hline チランナム & 5,260 & $60 \quad(1 \%)$ & 建設 & 北部都市，南部 \\
\hline グーフン & 7,856 & $600 \quad(8 \%)$ & 建設 & 北部都市, 南部 \\
\hline タインザン & 8,144 & $350 \quad(4 \%)$ & 建設 & 北部都市, 南部 \\
\hline ジエンホン & 2,916 & - & - & - \\
\hline ティエンフォン & 5,190 & $400 \quad(8 \%)$ & 建設 & 北部都市, 南部 \\
\hline
\end{tabular}

タインミエン県 18 社の人民委員会における聞き取り調査により作成。

—...不明。*… 数ヶ月の短期出稼ぎは人民委員会への届出をしないことが多いため、届出数と実数の 間に 2 倍から 10 倍近くの格差がある。したがって聞き取りによって得た出稼ぎ者の概数を用いた。括弧内 は，人口に占める出稼ぎ者の割合である。

農外就労機会を例にとってみてみよう。農閑 期に域内で木工，建設工などに従事した場合， 月収は 20 万〜 50 万ドンと出稼ぎ収入と大差がな い。したがって，出稼ぎに対する農村側の「押 し出し要因」は大幅に減少することになる。農 外就労機会が季節に左右されず高収益である場 合は，総労働人口に占める出稼ぎ者数の比率は さらに低い。たとえば出稼ぎ者が少ないチラン ナム社（比率は $1 \%$ ）の各村では，魚の人工睬 化業や菓子製造業，ダオ・コーという景勝地を 中心とした観光関連業が存在する。上述した小 規模な中心地の 1 つであるチュオン村（ラムソ
ン社）においても，商業やサービス業などの農 外就労機会が多いため, 出稼ぎ者比率は $2 \%$ と 少ない。こうした差異は出稼ぎの平均月収にも 表れている。社レベルでみても，25万ドン（ゴ ークエン社）～180万ドン（ドアントゥン社）と格 差は大きい。一方,「出稼ぎの伝統」という歴 史的な影響もある。チランバック社やドアント ウン社は，仏領期以前から出稼ぎを行っていた 村を含むため, 現在でも出稼ぎ者の人口比がそ れぞれ $26 \% ， 14 \%$ と他の社より高い。

以上のように，県レベルで分析を行うことに より，ドイモイ後，農家の農外活動が活発化し

36）パーンウェル（古賀正則監訳）『第三世界と人口移動』古今書院，1996，79-85頁。

37）たとえばドアントゥン社には仏領期からの伝統をもつ訪問販売があり，北は国境地帯から南はメコンデルタまで, ベト ナム全国へ出かけている。 
ていること，さらに村ごとに異なった展開をみ せていることも明らかになった。これは，個人 の経済活動が, 各々を取り巻く経済的背景や社 会的背景に影響されることに加えて，そうした 背景が村ごとに共有されているためであると考 えられる。この要因を探るため, 次章以下, 村 レベルに視点を移して, 農家の経済活動と社会 的ネットワークの関係を具体的に検討していき たい。

\section{III 経済活動の変容と農家の多角経営：村レ ベルの分析(1)}

(1)ドイモイによる農家間格差の拡大 対象 としたゴークエン社ファムタン村 (thôn Phạm Tận xã Ngô Quyền, 2001年現在で431世帯 1,320 人) は，タインミエン県の北西端に位置する。同村 は県境をなすキュウアン川の堤外地にある。そ のため農地の大半では; 冬春米 $(2 \sim 5$ 月 $)$, 雨 季米（７～10月）に加えて，畑作物（11月～翌年 1月）も栽培される。村に残る文書によると, 同村は約 300 年前に形成され，仏領期には既に 「自律的な共同体」を成していた。現在でも農 民にとって，社ではなく，村が社会経済活動を 行う主たる場であり，「おらが村」という村へ の帰属意識は鮮明である。「扔らが村」への思 いの強さは，同じ社内の他村との協調を困難に する。タインミエン県では社ごとに合作社があ
ったが，ゴークエン社では，1990年に村ごとの 合作社に分割した。同県ではいまだに唯一の事 例である。

この合作社分割の契機となったのが，農民へ の土地分配であった。タインミエン県では，土 地分配は, 1981年, 1988年, 1993年の 3 回実施 された。このうち1993年の土地分配は, 村ごと の合作社に分割された後に実施されたため，最 も混乱が少なかった。1993年の土地分配では, 実施時に誕生していた村民全員に一人あたり $504 \mathrm{~m}^{2}$ を平等に分配した。言い換えると，この 時点で土地分配の対象外とされた高額所得者 （教師，恩給受給者，県級以上の公務員など）を除 くと，村民は等しく「農民」となったのである。 ドイモイ後, 農家は兼業化も含めた経営の多 角化を進める傾向があり，村内でも農家間の経 済格差が拡大している。このことは，筆者が 2001年に農家に対して実施した世帯収入に関す るアンケート調査 (322世帯分) の結果からも明 らかである。同村の平均年収額は640万ドンで あるが，個別にみると最低では収入なしであり， 最高では2,500万ドンを超えている（第 4 図）。 収入源には，農業収入として(1)栽培（水稲，畑 作物，野菜)，(2) VAC（ブタ，ニワトリ，アヒルな どの家畜，家禽，水産，果樹を合わせた多角的な農 ( $\left.{ }^{42}\right)$, 農外業収入として(3)給与, (4)農外収入 (副業, 出稼ぎ), (5)仕送り, がある。農家の多

38）これは注7）ですでに触れた白紙請負制であり，ドイモイの胎動とみなされる。社規模で分配したため，農地が遠いな どの不満が多かった。

39）面積に加え土地条件の平等も追求されたことから，日本の小字に相当する伝統的な地割（xứ đồng）を細分した。この ため1世帯あたり10〜15筆を分散所有している。

40）土地分配が1993年に実施され，年齢や性別に関係なく平等に分配された点は県全体で共通しており，これは土地分配に 際して県の指導があったためである。しかし分配基準面積は合作社ごとに異なる。

41）431世帯のうち63世帯はファムタン村に戸籍を残したまま，北部山岳地域や中部高原へ移住していることから除外した。 また大多数の世帯が正確な収入額を把握しておらず，回答額も観察した生活水準や支出状況と整合しないなど信憑性を欠 く。そのため, 農産物 (水稲, 畑作, 果樹園芸), 家畜 (ブ夕, ニワトリ, ガチョウ, アヒル, ヤギなど), 水産物（魚， 稚魚など）の生産状況と販売額, 農地の賃借料, 給与収入, 農外活動収入, 年金·恩給収入, 仕送り額から推定年収を算 出した。

42）VAC は，庭 (vườn), 池（ao），家畜小屋（chuồng）という3つのベトナム語の頭文字を合わせた語である。初期投 資が50〜100万ドンと副業に比べて小さいこともあって，官民ともに志向する。

43）土地分配は個人に対して実施されたため; 夫が県の役人であって土地分配を受けていなくても，妻は土地分配を受けて いるという場合が多い。ここでは個人ではなく世帯を対象としていることから，世帯内に 1 名でも土地分配を受けた者が いる場合は統計の対象に含めている。 


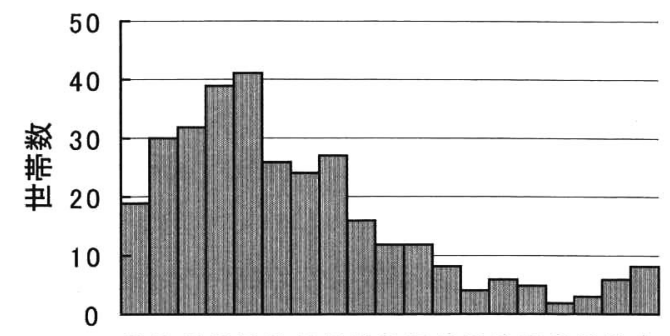

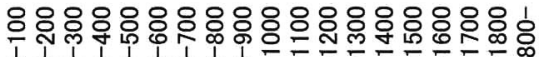

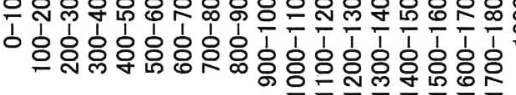

年収額 (万ドン)

第 4 図 ファムタン村における農家世帯あたり の年収分布

Figure 4. Distribution of agricultural household income in Pham Tan village

ファムタン村におけるアンケート調査により作成。

角化志向は, 全体の $65 \%$ 農家がVAC を行っ ており (第 3 表)，ほぼ全ての農家が複数の収入 源を有することからもうかがえる。農家の経営 形態は，この収入源の組合せ方法とそれぞれの 収入内訳が各農家の総収入に占める比率の違い によって，多様である(第 3 表)。最も多い組合 わせ型は，積極的な専業農家といえる稲作 VAC 農家 (1)+(2) である。ただし，その数は 58 にどまっており，全体の $18 \%$ を占めるにす ぎない。

農外活動に従事する農家は全体の約3分の $2 に$ 及ぶ。しかし総収入に占める比率をみると，農 業収入が主である農家が153世帯であるのに対 し，従である農家は72世帯である。つまり，ド イモイ期の農家の多くは農業活動を主としなが ら副次的に農外活動にも従事している。多角化 と並んで，この点も同村の農家経営の特徵であ る。

村全体としては農業収入が主であるとはいえ， 世带収入の階層性に注目すると, 高収入の農家 では農外収入の比率が高い。ファムタン村にお ける年収が1,000千万ドン以上の農家のうち,

主たる収入源が農業であるのは3世帯にすぎな い。他方, 農外活動は47世帯, 給与は15世帯に
第3表ファムタン村における収入源別農家世 带分類

Table 3. Agricultural household classification by income source in Pham Tan village

\begin{tabular}{|c|c|c|c|c|c|c|}
\hline & & 収入源 & & & 世 & 平均 \\
\hline $\begin{array}{l}\text { 栽培 } \\
\text { (1) }\end{array}$ & $\underset{\text { (2) }}{\mathrm{VAC}}$ & $\begin{array}{l}\text { 給与 } \\
\text { (3) }\end{array}$ & $\begin{array}{c}\text { 農外 } \\
\text { (4) }\end{array}$ & $\begin{array}{c}\text { 仕送 } \\
\text { (5) }\end{array}$ & $\begin{array}{l}\text { 霉 } \\
\text { 数 }\end{array}$ & (千ドン) \\
\hline (0) & 0 & - & -2 & - & 58 & 3,897 \\
\hline 0 & 0 & - & (O) 12 & - & 43 & 10,000 \\
\hline (O) & (a) & - & $\bigcirc 8$ & - & 29 & 8,077 \\
\hline (a) & - & - & -2 & - & 27 & 2,251 \\
\hline (0) & - & - & $\bigcirc 8$ & 一 & 24 & 4,963 \\
\hline 0 & 0 & (0) 5 & - & - & 22 & 9,355 \\
\hline 0 & - & - & (O) 5 & - & 19 & 6,224 \\
\hline (0) & (0) & 0 & - & - & 13 & 7,071 \\
\hline 0 & - & (O) 2 & - & - & 13 & 10,567 \\
\hline 0 & (D) & - & - & - & 9 & 4,723 \\
\hline (0) & - & 0 & - & - & 7 & 5,693 \\
\hline- & (0) & - & - & - & 5 & 1,442 \\
\hline 0 & 0 & 0 & (O) 2 & - & 4 & 10,501 \\
\hline (0) & (1) & 0 & - & 0 & 4 & 8,771 \\
\hline - & - & - & - & - & 4 & 0 \\
\hline- & - & (O) & - & - & 4 & 4,995 \\
\hline 0 & - & 0 & 0 & - & 4 & 9,674 \\
\hline (0) & (0) & - & - & 0 & 4 & 4,172 \\
\hline 0 & 0 & - & -1 & (0) & 4 & 7,330 \\
\hline 0 & 0 & - & $\bigcirc 2$ & 0 & 4 & 8,468 \\
\hline 0 & - & - & - & 0 & 4 & 2,650 \\
\hline- & - & - & - & (0) & 4 & 1,813 \\
\hline- & - & - & (0) & - & 3 & 6,133 \\
\hline (a) & (a) & 0 & 0 & - & 2 & 12,552 \\
\hline 0 & 0 & (a) & 0 & - & 2 & 16,447 \\
\hline- & - & - & (0) 1 & 0 & 1 & 4,800 \\
\hline- & - & (2) & - & 0 & 1 & 1,304 \\
\hline- & 0 & (a) & - & - & 1 & 4,800 \\
\hline- & 0 & (a) & - & 0 & 1 & 3,215 \\
\hline 0 & - & (0) & - & 0 & 1 & 5,750 \\
\hline (2) & $\mathrm{O}$ & $\mathrm{O}$ & $\mathrm{O}$ & 0 & 1 & 10,654 \\
\hline
\end{tabular}

ファムタン村におけるアンケート調查（2001年）により作成。

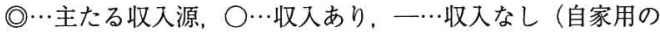
み)。右側の数字は村外での就労数である。

のぼっている。これは, 同村においては, 農業 活動の基本となる農地面積が狭小であるうえ， インフラが不十分なことから, 商品作物の栽培 
が難しいというマイナス要因があるためである と考えられる。ただし，農業活動においてもマ イナス要因を克服することで高収入を望める可 能性がある。実際に，上述した 3 世帯はいずれ も農地増反を行っている。

それでは，このように経済活動が多角化して ゆく過程で，本論の主題である社会的ネットワ ークはどのように関わっているのであろうか。 以下，農業活動と農外活動のそれぞれで検討し てみよう。

(2) 農業活動の展開と農地貸借の進展 ドイ モイは農家の増産意欲を刺激し, 農業の土地生 産性を増加させた。しかしドイモイ後, 米価は 低迷しているのに対して, 化学肥料や農薬とい ったコストが年々増加し，農家に新たな負担を もたらした。紅河デルタの他農村と同様に, 同 村でも潜在的な失業者（特に農䦥期）が多いこ とも問題となっている。そこで，1990年代以降， 資本のある農家，あるいは社会的ネットワーク を通じて資金を都合できる農家は，VAC 農法 を積極的に導入して，所得拡大を図っている。 VAC は，余剩米を飼料として有効利用し，か つ余剰労働力を投下できるという，合理的な農 法でもある。一般には, 最初はライチなどの果 樹を庭先に植樹したり，ニワトリ・アヒル・ガ チョウの幼鳥を購入して飼育するといった，資 本投下が少ない（10万ドン以下）ものから始め, 次段階として，まとまった投資額（50１00万ド ン）が必要なブタの肥育を取り入れる。さらに, 池を借りて養魚を営んだり, 水田や堤外地を借 りて $\mathrm{VAC}$ 園地に転用するなど，VACに本腰 を入れている農家もみられる。

農民がVACをはじめる際は，「うちの村の $\mathrm{A}$ さんがライチを植えて，今年1千万ドン儲け た」,「今はライチが儲かると，合作社の Bさ
んが言っていた」といった，知り合いを通じて 得た情報が契機となる場合が多い。つまり農民 は，社会的ネットワークでやりとりした情報を 最も信頼し，それによって自らの意思決定を行 っているといえる。ファムタン村では, ドイモ イ後, 多くの農家が収益性の高いライチに集中 したために，逆に供給量が過多となり，販売価 格が半減してしまったという負の作用までもみ られた。

ところで農民が VAC を導入したがる現象は， 一方で換金性の高い農畜産物の栽培という農民 の志向として捉えられ，他方で天候不順や病虫 害被害，不安定な市場に対する危険分散という， 農家の対処法として捉えることができる。この 2 点は，農家の VAC 以外に対する意思決定に も反映されている。農業活動の中心である水稲 栽培の場合をみてみよう。近年，市場価格が高 く味の良い品種の作付面積が増加している。し かしそうした品種は, 紅河デルタで頻発する旱 魅や低温, 洪水, 病虫害などの被害に弱い。さ らに高価格を期待して作付しても，見込んだ販 売価格が持続される保証はない。そのため，1 農家あたり最低でも 3 品種，多い場合には 6 〜 7 品種を栽培している。このことからも, 農家 を取り巻く不安定要因が, 農家に多角化を選択 させていることがわかる。

さて，農業にとって第一の規定要因となるの は，経営規模つまり農地面積である。しかし， 農家間の格差拡大はここでも顕著である。1993 年の土地分配からわずか 8 年後の 2001 年現在で, 3 分の 1 強に相当する 111 世帯が増反しており， なかには経営規模の半分以上が増反分である世 帯もいる(第 5 図)。農地の増減反は，譲渡では なく貸借によるものである。土地使用権の譲渡 による課税を避けるためとも考えられるが，多

44）冬春米は旱魅や冷害の被害, 雨季米は洪水の被害に襲われることが多い。

45） 1993年の土地法では土地使用権に譲渡や相続も認められているので, 農地の売買も行われている。ファム夕ン村では, 言葉としては「売買 (mua bán)」という語が使用されているが, 実態は「賃借」である。 
（借地面積）

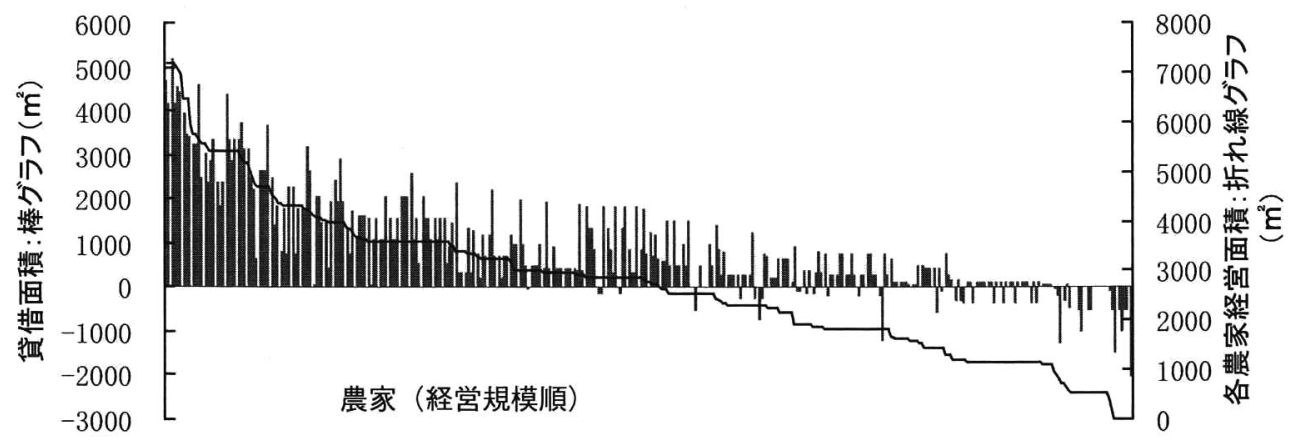

（貸地面積）

第 5 図 ファムタン村における農家の経営規模と農地の貸借

Figure 5. Management scale of farms and balance of acreage in Pham Tan village

ファムタン村におけるアンケート調査により作成。

くの場合，賃料だけでなく契約期間も設定され ていることから, 将来の不測時の生活保障とし て農地を保有しておきたいという農家の意図も みえる。さらに特徵的なことは, 土地貸借が親 族間で行われる場合にも，賃料と期間を設定し た経済行為として執り行われる点である。実際 に，親族間の貸借 111 例のうち，81例の貸し手 は老龄の親・親族や他村へ嫁した姉妹，出稼ぎ に行った親族であり，このうち57例は直系の親 族か兄弟姉妹といった近親者であった（第 4 表）。 しかし，無償の事例はわずか 10 例，期間不定の 事例も29例にすぎない。

血縁関係もまったく無意味なわけではない。 賃料は年間 1 サオ $\left(1 \mathrm{sào}=360 \mathrm{~m}^{2}\right)$ あたり 14 万〜 30 万ドンと約 2 倍の格差があるが, 通常, 近親 者間の貸借の方が低額に設定されている。経済 的に逼迫している親族に対しては廉価で貸す事 例も多くみられる。たとえば，無償の貸借は， 娘から親へ 3 例，息子から親へ 1 例，親から子 へ 4 例（夫方・妻方 2 例ずつ），姉妹から兄弟へ 2 例，とすべて近親者間で行われていた。親族 に次いで多いのは，同じ村の住民間の19例であ り，他村の住民との間の 7 例とは差がある。農 地の貸借は，このように主として地縁・血縁と いった旧来の社会的ネットワークに依存してい
第 4 表 農地貸借の実態

Table 4. Situation of acreage for tenants

(2001年現在)

\begin{tabular}{|c|c|c|c|c|c|c|c|c|}
\hline & \multirow{3}{*}{$\begin{array}{l}\text { 畣 } \\
\text { 計 } \\
\text { 世带 }\end{array}$} & \multicolumn{6}{|c|}{ 村内 } & \multirow{3}{*}{$\begin{array}{l}\text { 村 } \\
\text { 外 }\end{array}$} \\
\hline & & \multicolumn{4}{|l|}{ 親族 } & \multirow{2}{*}{$\begin{array}{l}\text { 共 } \\
\text { 有 } \\
\text { 地 }\end{array}$} & \multirow[t]{2}{*}{ 個人 } & \\
\hline & & 計 & 直系 & $\begin{array}{l}\text { 兄弟姉妹 } \\
\text { (内既婚) }\end{array}$ & $\begin{array}{l}\text { その } \\
\text { 他 }\end{array}$ & & & \\
\hline 無償 & 10 & 10 & 8 & $2(2)$ & 0 & 0 & 0 & 0 \\
\hline 有償 & 101 & 71 & 33 & $14(8)$ & 24 & 4 & 19 & 7 \\
\hline 合計 & 111 & 81 & 41 & $16(10)$ & 24 & 4 & 19 & 7 \\
\hline
\end{tabular}

ファムタン村におけるアンケート調査および聞き取り調查に より作成。

る。

ところで, 農地の貸借は, 出稼ぎの増加と農 地面積の不均衡化をうけて, 1995年以降に盛ん になっている。すなわち，出稼ぎが長期化する につれて農繁期の人手不足が問題となり，これ が農地を貸す契機となる。さらに，1997年頃か らべトナム中部への挙家移住が増加しており， これらの世帯の農地が, 貸し出されるようにな った。こうした貸す側の事情がある一方で，借 りる側の事情もある。1993年の土地分配以降, その調整が行われていないことから, 新たに誕 生した子どもや村外から嫁いできた女性には農 地がなく，一部の農家では生活のために農地を 借りざるをえないという事情が生じている。以 
上のような事情は，今後さらに進展してゆくと 予想されるために，土地使用権の異動は加速化 していくと考えられる。

このような農地貸借をめぐる動きから，以下 の三点を指摘できる。第一に諸個人間の社会的 ネットワークが経済活動に利用されており, 強 い絆で結ばれたネットワークほど重要な転機に 利用される点, 第二に各個人が, 社会的ネット ワークをドイモイという変動期における適応戦 略として有効化している点，第三に逆に親子の 情といった精神的絆や顔見知りといった社会関 係が一方的に経済活動に作用しているのではな く，金銭的対価を伴う貸借という経済的行為に よって，そうした社会関係が確認され，強化さ れている点である。特に第三の点は，紅河デル 夕農村における社会的側面と経済的側面の連動 を示しており，この地域の特徵を考えるうえで 重要となろう。

( 3 ) 在村の農外活動と社会的ネットワークの 展開 II 章で既に述べたように，ドイモイ期の 農村では農業経営の多角化と並んで，農外活動 の活発化が顕著である。まず村にとどまりなが ら農外活動に従事する場合に注目してみよう。

ファムタン村では94世帯が農外活動に従事し ており, 食品加工業, 運搬業, 建設業, 木工業, 仕立て業, 精米業, 小売業などを副業として営 んでいる。副業による収入は，事業規模や労働 投下の度合いによって異なり，月に10万〜 200 万ドンと格差が大きい。また農業活動でVAC への志向が顕著であるのと同様に，農外活動に おいても経営が小規模で多角的であるという傾 向がみられる。副業の従事者が世帯内で 1 名の みである場合が 69 世帯を数え, 複数の業種に従 事する場合は21世帯を数えた。

農民は, こうした農外活動へどのような過程
を経て参入してゆくのであろうか。一例をあげ てみよう。Cさんは1992年に軍隊から復員した 後, 別の村に住むかつての同級生が豆腐製造で 成功したのを知った。そこで，叔父から借金を してタインミエン町で機材を購入し，みようみ まねで豆腐製造を始めた。原料の大豆は社内の 市場か, 不定期に訪れる馴染みの行商人から購 入した。「苦労の甲斐」あって，親族や隣近所 を中心に顧客が徐々に増加し，現在は収入も安 定している。この事例のように，社会的ネット ワークを通じて，資金の調達，雇用先や報酬お よび顧客に関する情報，技術の獲得など，農外 活動に不可欠な情報や手段を獲得する事例は， 他にもみられた。

一方, ドイモイ後, 農外活動が農家に収入増 加をもたらしたことにより，社会的ネットワー クも活性化している。たとえば，村祭の復活や 父系親族集団であるゾンホ (dòng họ) の活性 化など，既存の社会的ネットワークが一部で強 化されている。また，社会主義化の過程で政治 的に組織化された農民会・婦女会・退役軍人会 などの大衆組織（tổ chức quần chúng）が，共同 体的機能の一端を担うようになるといった動き や，同空会や軍隊の同期会の結成といった新た な動きもみられる。ゾンホや大衆組織のなかに は，近年，独自の基金を創設しているものもあ る。基金は組織の活動資金となる一方で，メン バーに対して単年決済の小規模融資を行い, VAC や副業を起業する際の初期資金を提供す る。つまり，ここでも社会的側面と経済的側面 が連動している。

以上述べてきたように，ファムタン村におい ては, ドイモイ後, 農家経営の多角化が進み, 農業活動, 農外活動の両方が多様な展開を示し ている。その過程で社会的ネットワークは経済

46）親世代の高齢化や死去によって，基準以上の農地を保有する農家が存在する，と言い換えることができる。

47）これらは50万〜100万ドンと小規模であるが，手続きが簡略なこともあって，農民にとっては利用しやすい。ただし， 多くの場合, 創設が1990年代半ば以降と新しいため資本総額は少なく、融資件数も年に数件程度である。 
第 5 表 ファムタン村における出稼ぎの類型と属性

Table 5. Type of migrant labor and its attribute in Pham Tan village

(2001年現在)

\begin{tabular}{|c|c|c|c|c|c|c|c|c|}
\hline & \multirow{2}{*}{ 期間 } & \multirow{2}{*}{ 距離 } & \multirow{2}{*}{ 農家数 } & \multicolumn{4}{|c|}{ 人数 (人) } & \multirow{2}{*}{$\begin{array}{l}\text { 年齢層 } \\
\text { (歳) }\end{array}$} \\
\hline & & & & 全体 & 世帯主 & 女性 & 未婚 & \\
\hline $\mathrm{A}$ 農䦥期出稼ぎ & 数ヶ月 & 近-中 & 29 & 30 & 24 & 1 & 1 & $19-44$ \\
\hline B 中期出稼き & 1-2年 & 中-遠 & 8 & 8 & 3 & 1 & 1 & $19-41$ \\
\hline C 長期出稼ぎ & 数年 & 遠 & 13 & 13 & 8 & 0 & 1 & $17-60$ \\
\hline $\mathrm{D}$ 海外出稼ぎ & 数年 & 海外 & 5 & 5 & 5 & 0 & 0 & $33-38$ \\
\hline
\end{tabular}

活動に不可欠な要素として利用され，同時に経 済活動に利用されることによって強化されてき た。また市場経済原理からみれば非効率ともい えるほどの多角化は，そうした個人や各農家を とりまく社会的ネットワークが経済活動に活か された結果であり，多様な機会を捉えて経済的 安定や生活水準の向上を図ろうとする農民の意 思決定の現れであるといえよう。

\section{IV 出稼ぎの展開と社会的ネットワークの利} 用：村レベルの分析(2)

(1)出稼ぎの形態と社会経済的背景 II 章3 節で述べたように, ドイモイ後, 出稼ぎが増加 しており，農家の重要な現金収入源となってい る。出稼ぎは，その期間に応じて，（A）農閑 期出稼ぎ，(B) 中期出稼ぎ，（C）長期出稼ぎ, （D）海外出稼ぎ，の 4 つに区分される（第 5 表)。ベトナムでは, 依然として農業が経済活 動の中心である。そのため, 農業活動が出稼ぎ 期間を規定しており, 出稼ぎの半数以上は，農 業と兼業する（A）である。

ファムタン村の例をみてみよう。同村では, 2001年現在で，55世帯56人が出稼ぎを行った。 このうち 40 人は，20歳前後から40歳代前半の働 きざかりの世帯主（男性）であり，そのうちの
30 人は農繁期には農業に従事する，(A）であ った。農繁期に帰郷する理由は，自分が手伝え ば，世帯外から人夫を雇う必要がないからであ る。1日 1 人あたり 2 万ドンの前後の労賃は, 大多数の世帯にとっては大きな負担となるうえ， 家の仕事を他人任せにすることには個人的にも 社会的にも抵抗感が強い。他方，農繁期に帰村 しない（B）の 8 人のうち 7 人は，親と同居し ており，世帯内に十分な労働力があるため，農 繁期の帰郷をそれほど考慮していない。

（B）と（C）は，出稼ぎ期間が長いことに加 えて, 移動距離も長い傾向がある。実際に親戚 がいる，実入りのよい仕事があるという理由で， $1,000 \mathrm{~km}$ 以上離れた，ベトナム南部へ出かける 場合もある。この場合, 親族の存在が重要な要 素となる。出稼ぎ先に扔ける, 親族の初期段階 の支援は仕事や生活を軌道にのせるために重要 であるし，村に残した家族の世話を頼めるのも 親族だからである。このように親族は，単に有 益な情報をやりとりするにとどまらず，物質 的・心理的に支援してくれることから，個人が 有する数ある社会的ネットワークのなかでも， 最も頼もしい存在であるといえる。

出稼ぎは，近年，新たな展開をみせている。 出稼ぎ先での生活に余裕がでた出稼ぎ者が，出

48）ベトナム国内の都市一農村間の労働移動は, (1)長期（農繁期にも帰村しない)，(2)中期（農閉期のみ出かけるので労働 期間は年 3 ヶ月 $\times 2$ 回の 6 ケ月)，(3)日帰り（農繁期は農業に従事）の 3 つに区分される（小川有子「村落内雇用の実態 調查」(『べトナムの労働事情』日本労働研究機構, 2000）47-64頁)。本稿では農村社会の重要な行事であるテト（旧正 月）に参加するか否かを重視し，(1)の長期を 1 年と数年に 2 分した。また同村には国外への出稼きも行われている。 
第 6 表 ファムタン村における出稼ぎ

Table 6. Migrant labor in Pham Tan village (2001年現在)

\begin{tabular}{|c|c|c|c|c|}
\hline & 職種 & 数 & $\begin{array}{c}\text { 月収 } \\
\text { (万ドン) }\end{array}$ & 行き先 (人数) \\
\hline 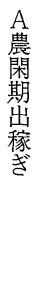 & $\begin{array}{l}\text { 建設 } \\
\text { 炭鉱夫 } \\
\text { 行商 } \\
\text { 日雇い労働. } \\
\\
\text { 運転手 }\end{array}$ & $\begin{array}{c}9 \\
2 \\
13\end{array}$ & $\begin{array}{l}35-50 \\
30-60 \\
30-100 \\
20-100 \\
\\
100\end{array}$ & $\begin{array}{l}\text { バックカン省 (2) } \\
\text { 不定 (3) } \\
\text { クアンニン省 }(9) \\
\text { クアンニン省 (2) } \\
\text { クアンニン省 }(3) \\
\text { バックカン省 }(2) \\
\text { ホーチミン市 }(1) \\
\text { 不定 }(7) \\
\text { ハイズオン市 }\end{array}$ \\
\hline $\begin{array}{l}\text { B } \\
\text { 中 } \\
\text { 期 } \\
\text { 虫 } \\
\text { 稼 } \\
\text { き }\end{array}$ & $\begin{array}{l}\text { 炭鉱夫 } \\
\text { 貸金労働 } \\
\text { バイク修理 } \\
\text { 木エ }\end{array}$ & $\begin{array}{l}3 \\
3\end{array}$ & $\begin{array}{l}50-60 \\
30-80 \\
\\
50 \\
40\end{array}$ & $\begin{array}{l}\text { クアンニン省 }(3) \\
\text { ハイズオン省 }(1) \\
\text { クアンニン省 }(1) \\
\text { ハイフォン }(1) \\
\text { バックカン省 } \\
\text { 南部 }\end{array}$ \\
\hline $\begin{array}{l}\mathrm{C} \\
\text { 長 } \\
\text { 期 } \\
\text { 虫 } \\
\text { 稼 } \\
\text { き }\end{array}$ & $\begin{array}{l}\text { 電気工 } \\
\text { 建築技術者 } \\
\text { 軍隊 } \\
\text { 木工 } \\
\text { 賃金労衝 }\end{array}$ & $\begin{array}{l}3 \\
1 \\
2 \\
1 \\
6\end{array}$ & $\begin{array}{l}100-180 \\
80 \\
50-100 \\
50 \\
30-40\end{array}$ & $\begin{array}{l}\text { ダックラック省 (2) } \\
\text { ハイズオン市 }(1) \\
\text { ハイズオン市 } \\
\text { フンイェン市 }(2) \\
\text { バックカン省 } \\
\text { ダックラッ省 (4) } \\
\text { ハーバック省 }{ }^{(1)} \\
\text { ザライ省 }(1)\end{array}$ \\
\hline $\begin{array}{l}\text { D } \\
\text { 海 } \\
\text { 出 } \\
\text { 嫁 } \\
\text { き }\end{array}$ & 賃金労働 & 5 & $300-850$ & $\begin{array}{l}\text { リビア (1) } \\
\text { チェコ (1) } \\
\text { 韓国 (3) }\end{array}$ \\
\hline
\end{tabular}

ファムタン村におけるアンケート調査および聞き取り調査に より作成。

稼ぎ先で生活の基盤を築き，村に残した家族を 呼び寄せている。このような挙家移住の事例は, 2001年現在で63世帯ある。ただ，この場合で も大多数の世帯は戸籍や土地家屋を村に残した まま移住し，親族に農地の管理を託している。

（D）は，政府の斡旋が必要であるため，他 の場合とは大きく異なり，登録時までに多額の 費用を工面できるという経済条件が決定的な意 味をもづ。金融機関の利用がまだ一般的でない
ベトナムでは，資金を都合する場合には，親族 や知人からの借金に頼ることが多い。したがっ て，海外出稼ぎにおいても親族の存在は大きい。

(2) 出稼ぎの種類と社会的ネットワークの関 係 既に述べたように，農業活動との関わりに よって，期間や移動距離といった出稼ぎの形態 は異なっている。この差異は, 出稼ぎ者の職種 や収入にいかに影響するのであろうか。ファム タン村で最も多い，(A）からみていこう。30 人のうち半数近い 13 人は, 日雇い労働に従事し ており，そのうち10人は行き先も一定でなかっ た (第 6 表)。収入は，仕事の有無や出稼ぎ者の 技術程度によって異なり，月に20万〜 100 万ド ンと格差が大きい。

（B），(C）と出稼ぎが長期化するにつれて, 技術職をはじめとした，より専門的な職種や常 勤職が増加する。これは出稼ぎ者の技術程度に もよるが, 出稼ぎ先や村内に拉ける人脈とも大 いに関係する。その意味で, 出稼ぎ者にとって は，一般的な都市側の「引き寄せ要因」よりも， 彼ら自身の社会的ネットワークが出稼ぎ先の決 定に関わっているといえる。だからこそ，出稼 ぎ先は必ずしも最寄りの地域や都市部とは限ら ず，遠方や僻地へも出かけるのである。ハノイ， ハイフォンという紅河デルタ内の二大都市への 出稼ぎは強い「引き寄せ要因」をもつと考えら れるにもかかわらず，実際には，これらの都市 への出稼ぎは散発的であり, 出稼ぎ先は約 $300 \mathrm{~km}$ 離れた中国国境に近い北部山岳地域の バックカン省から $1,000 \mathrm{~km}$ 以上離れたベトナム 南部のホーチミン市までと広域に及ぶ（第 1 図)。さらに出稼ぎ先は, 北部ではクアンニン

\footnotetext{
49）この63世帯は長期で村に不在のため, アンケート調査の対象には入っていない。したがって先に出稼ぎ世帯として抽出 された55世帯とは別である。

50）なお，彼らは数年に一度は帰村して村との関係も保持することが多い。そのため，本人にとっても親族にとっても「出 稼ぎ」なのか「移住」なのか明暸でない場合が多い。

51）政府の労働輸出入公社に登録しなければならない。契約料は渡航費や，保証金，手数料などを含む。行き先によって異 なるが, 非常に高額である（たとえば日本の場合は 1 億ドンを超える)。したがって，ごく限られた世帯でのみ可能となる。

52）前掲36), 79-85頁。
} 
省に 18 人，中部ではダックラック省に 6 人と， 特定の場所に集中するが，ホーチミン市以外は 大都市でない。

農家にとって出稼ぎの動機は，いうまでもな く現金獲得である。しかし, 出稼ぎ先や職種の 選択は, 親族, 同村出身者, 就学時代の同級生, 軍隊の同期入隊者といった顔見知りによっても たらされる情報に大きく左右される。言い換え れば, 結果的に村における出稼ぎ者の行動選択 が類似するのは, 出稼ぎという経済活動におい て個人の社会的ネットワークが不可欠な要因と なっているためであり，なおかつ社会的ネット ワークのなかでも, 地縁・血縁といった従来の 関係が，いまたにたきな意味を持つためである といえよう。

(3)社会的ネットワークの展開と再生産 出 稼ぎ者は，自らの社会的ネットワークを主たる チャネルとして重要な情報をやりとりし, 生活 の相互扶助や心理的な支援を提供し合う。そう して新たな出稼ぎ者が連鎖的に生み出されてゆ く。たとえばCさんの場合, 1996年にハイフ オン市に駐屯していた軍人の弟を頼って娘を仕 立て見習いに出し，娘が独立した1999年には， 自身が娘を頼ってハイフォン市へ移り，日雇い 労働に従事した。生活が安定すれば，「妻と就 学期の息子も呼び寄せ, 土地家屋は信頼できる 親族の誰かに貸すつもりだ」，とCさんはいう。

さらに大きな動きとして，1990年代半ば以降， ダックラック省への連鎖移動 (chain migration）が起こっている。ファムタン村の $20 〜 30$ 世帯が漸次移住し, 主にコーヒー栽培に従事し てきた。1990年代末からは，20歳前後の若年層 が，既に移住した親族を頼って移動している。 この場合, 紅河デルタ地域にある諸大学と比べ て難易度が低い, ダックラック省の師範大学や
自動車教習学校へ入学し, 安定して高収入が見 込める資格を取得することが目的に加わる。つ まり, 次世代の経済活動の展開に向けても, 社 会的ネットワークが利用されている。

このような連鎖的な動きがみられる一方，出 稼ぎには組織化もみられる。ファムタン村では $3 \sim 6$ 人規模のトー（tỗ組, 以下組と称す）や, 数十人規模のドイ（đồi 隊，以下隊と称す）と呼 ばれる出稼ぎ集団が形成されている。組は, 地 縁・血縁に加えて, 同級生や軍隊への同期入隊 者など信頼のできる顔見知り関係で形成される。 組のメンバーはリーダーを核にして形成される ことが多いので，その組成はリーダーに左右さ れる。単なる地縁・血縁関係は重要視されない が，出稼ぎ者集団としての持続性は強い。また， 就く職種は年によってさまざまであり，近距離 のベトナム北部都市への出稼ぎが多いという特 徵もある。たとえばある組の場合, 現在のメン バーは Dさん, Dさんの甥, Dさんと同期に 入隊した友人 3 名（うち 2 名は村外出身者）であ り，1998年からハイズオンや，クアンニンなど のベトナム北部の諸都市で, 日雇い労働に従事 してきた。2000年に同期入隊者であった 1 名が 出稼ぎをやめた時, 中心人物である Dさんが 自分の甥を推挙して, メンバーを補充し, 現在 のようになった。彼らは出稼ぎ先で共同生活を 営むことから,「気心の知れた信頼の打ける 人」しか仲間として受け入れない。

一方，隊は20３0人程度と大規模であり，特 定の仕事のために組織される点で組とは異なる。 従事する職種は炭鉱夫や建設夫など多岐に亘り， その内容によって隊の規模も異なる。たとえば, 1996年まで北部山岳地域で行っていた井戸掘り では，従事者は最盛期には 50 人に及んだ。請負 う仕事の規模が大きく，長期にわたる場合が多

53）ダックラック省への移住に関しては, Stan B-H Tan, 'Coffee frontiers in the Central Highlands of Vietnam: networks of connectivity' ,Asia Pacific View Point,41-1, 2000, pp.51-67などを参照。 
いために，隊には組の場合よりさらに責任能力 のあるリーダーが求められる。彼は自らの社会 的ネットワークを活用して, 仕事の請負や仕事 に応じた隊員の選定，さらに熟練度に応じた賃

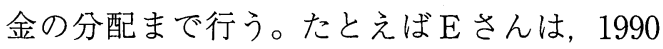
年代に入ってから毎年, 北部ベトナム地域, 特 に北部山岳地域を回って仕事を探し，請け負っ た仕事に応じて，自分の親族や知人を主たるメ ンバーとして隊を編成してきた。

このように同じく出稼ぎ集団であっても，組 と隊は規模や従事する業種, 集団編成が異なっ ている。そのうえ, 隊では技能や経験, 年齢に 応じた役割分担とそれにともなう階層性がみら れるのに対し，組ではメンバー間の人間関係や 仕事量は同等である。この違いは, 集団編成に あたって，隊では地縁・血縁が, 組では個人の 関係が，それぞれ重視されることと関係があろ 门。

以上述べたように, 地縁・血縁や同級生, 同 期入隊者同士といった社会的ネットワークは出 稼ぎの契機となり，いわば各人の経済的な向上 のために活用されている。一方では，出稼ぎ集 団に拉いて，恒常的な集団編成が契機となって 新たな仲間意識が生れている例が示すように, 出稼ぎが活発化することによって，社会的ネッ トワークも強化されているのである。

\section{$\mathrm{V}$ おわりに}

本稿では, ドイモイ期の紅河デル夕農村を対 象として, 経済活動と社会的ネットワークが相 互に連動していることを, 個人・農家レベルに おける経済活動の実態を分析をすることによっ て明らかにしようとした。この視点は, ベトナ ム農村が自律的な共同体であるとする，従来の ステレオタイプ化されたイメージを再考し，そ の枠組みの下で経済的側面と社会的側面は対立 ないし矛盾するとしてきた捉え方から抜け出て， 新たな視点を提示する試みであった。
1986年に導入されたドイモイは, ベトナム経 済を成長させた。農村部においても，農業活動 と農外活動の両方が活発化しているが, その状 況には地域差がみられた。地域差は，紅河デル 夕の農村が旧来から有している，個々の社会的 背景の相違によって生み出されている。本稿で は，地域を重層的に捉えながら県というメソス ケールでの分析を進めることによって，この相 違がドイモイによる市場経済化にいかに作用し ているかを明らかにした。

社会経済的背景が共通する同一村内の農家間 においても，市場経済の浸透度の相違に応じて， 経済格差が拡大している。これは，1993年に実 施された土地分配後わずか 8 年の間に農家経営 の多角化が進んだこと，また農地の利用が一部 の農家へ集積しつつあること，という2点から も理解できる。このような変化は，自然条件や 市場に多くの不安定な要因を抱える紅河デル夕 において，そこに住む農民が行った意思決定の 結果として捉えることができる。

ドイモイ期にあって, 各農村の経済活動は, 稲作を中心とした従来の形態から VAC やさま ざまな農外活動を導入した多角経営へと変化し ている。その過程において重要な意味を持つの が，個人や農家をとりまく社会的ネットワーク であった。このネットワークも経済活動の多角 化や空間的な広がりによって，同一村内での地 縁·血縁関係を中心としたものから, 各村の単 位を超えて広域化するものへと変化している。 すなわち，農村の経済活動とそこにみられる社 会的ネットワークは，相互に作用しながら展開 しており，ドイモイがこの連動をいっそう進め てきたと捉えることができる(第6図)。

社会主義化の過程で，国策によって作られた 農民会・婦女会・退役軍人会などの大衆組織も, 結成当時の目的とは異なる価值づけをなされな がら，今日では農村の紐帯として機能している。 さらに出稼ぎ集団の組織化もみられ，新たな社 
会的ネットワークが形成されつつある。

紅河デルタに抒ける社会的ネットワークは, 匿名でない，いわば顔見知りの関係である。こ れは，日本のように個人が集団の中に埋没して しまう社会関係とは対照的である。したがって， ベトナムの社会的ネットワークは個人の経歴の 中で形成されてゆくパーソナルなネットワーク であり, 経済活動によって常に再生産され, 強 化されてゆくものである。親子の関係も, 農地 の貸借あるいは譲渡という経済的行為を通じて 新たな意味を付与されていると捉えることがで きる。

このような社会的ネットワークの展開は, 紅 河デル夕社会の本質をあらためて考察しなけれ ばならないという課題を提示している。すなわ ち，ドイモイ期にある社会的ネットワークのあ り方を分析することによって，冒頭でも指摘し た，ステレオタイプ化され静態的に捉えられて きた紅河デル夕農村の自律性を, 社会経済的プ ロセスの中で再考することができると考える。 また, 桜井（1987）が提起したように, ベトナ 厶農村を動態的に把握することや，農村形成の 契機とその再編を考察することも可能となる。 ベトナムにおいては，農村部のみならず都市部 においても, パーソナルなネットワークが重要 な意味を持つ。したがって，この分析はベトナ ム社会の基本的特質を究明する糸口ともなろう。

ドイモイは, 経済活動の活発化を媒介として, 個人を結ぶ社会的ネットワークをも活性化させ ている。同時に，農村社会を基盤とした従来の ネットワークを村域外へ拡大させている。近年 は, 個人の生活領域が, 経済活動のみならず, 高等教育の普及や徴兵制によっても，村をこえ て拡大している。そのため, 同級生や同期入隊 といった自らの経歴や資質によって生み出され る新たなネットワークが広がりはじめている。 これらは社会的ネットワークとして，今後さら に重要性を増してゆくであろう。またそうであ

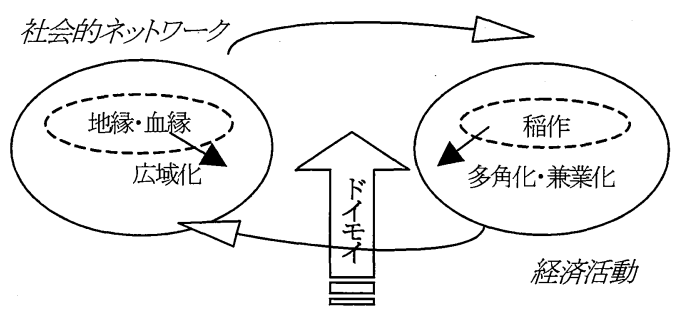

第6図ドイモイ期の紅河デル夕農村における 社会経済モデル

Figure 6. Socio-economic model of rural village in the Red River Delta under Doi Moi

るとすれば，地縁・血縁といった既存のネット ワークによって成立していた農村の経済社会構 造も，変質していくことが予測される。

本稿の目的は, 社会的ネットワークと経済活 動がいかに連動しているかを解明することにあ つた。そのため，個々の社会的ネットワークの 実態については多く触れることができなかった。 紅河デル夕社会の本質を追求するためには，こ れらの再生産や変質の過程を，たとえば出稼ぎ 者を受け入れた地域の側から明らかにしてゆく ことも必要となろう。

[付記］調查を行うにあたり, タインミエン県 の方々にご協力いただき, ベトナム国家大学ハノ イ理科大学地理学部の Dang Trung Tu君, Tran Danh Tuan 君, Tran Anh Tuan 君の 3 人 にはアシスタントとして助けていただいた。

Nguyen Cao Huan 助教授をはじめとするべトナ ム国家大学ハノイ理科大学地理学部の先生方, 奈 良女子大学文学部の戸祭由美夫先生, 松本博之先 生, 関西大学文学部の野間晴雄先生には, 本稿を まとめるにあたってご教示いただいた。心より感 謝申し上げます。本調查は, 平成13年度科学研究 費特別研究員奨励費（研究課題名：ベトナム紅河 デル夕農村における共同体と自律的農村発展への 展望に関する地理学的研究, 研究代表者: 原田由 起乃）を受けて行った。な打本稿は，2002年日本 地理学会秋季大会において発表した内容を基にし ている。 


\title{
Economic Activity and Social Network during Doi Moi in Rural Village of the Red River Delta, Vietnam: A Case Study of Thanh Mien District, Hai Duong Province
}

\author{
TsuTsuI Yukino \\ Faculty of Letters, Otemon Gakuin University
}

The Doi Moi (renovation) policy, which started in 1986, converted a planned economy into a market economy. As a result, the economic growth has been remarkable. The effect of this policy has reached even to rural areas and stimulated not only agricultural activity but also side activities like family handicrafts, retail, peddling, seasonal labor, and so on. Moreover, this economic transformation has brought social transformation to Vietnam and this is the reason why Doi Moi is considered as a big turning point for Vietnam.

Incidentally, Doi Moi has occurred in a rural village in the Red River Delta, northern Vietnam, an area which is characterized by its "autonomy of rural villages" and strength of social bonds. Hence, each rural village in the Red River Delta is wealthy in its uniqueness and diversity.

The autonomy of villages is considered to be the proximal layer of the Vietnamese society, as shown with term "traditional village." How should we grasp this social proximal layer during the drastic transformation of Doi Moi? It is true that autonomy declined once during the socialization of totalitarianism. However, this autonomy has been activated again under Doi Moi, which can be clearly shown by the reconstruction of such common values and property as the communal house, temple, and village festival, which has enriched the social organization in the village.

This is to say, Doi Moi has activated not only the rural economy but also the rural society. Yet it is common for economic and social concerns to be discussed individually or in opposition to each other. This is because the comprehension of social mechanisms is different from the comprehension of economic ones; the former is considered to be rational and based on the principle of the market economy but the latter is considered to be under traditional social rules.

I, however, think these two are connected to each other. In fact in the Red River Delta, the social network is used practically in the development of economic activity; furthermore, social network is strengthened by utilization in economic activity. The purpose of this paper is to prove this hypothesis and to examine the action between social network and economic activity at the micro level of individuals and households, which reflects these connections much more than when looking at the whole village. This is because individuals are the main components of a rural village and the practical decision makers for the economic activity and the social activity there. Here I will use the term "social network" to refer to the whole "face to face" personal network including both long-established relations based on relatives and the local community as well as newly established relations through personal stages of life like schoolmates and comrades in arms.

Moreover, this paper aims to analyze on a plural scale: the village level is the micro scale (main scale of this paper) and district level is the mezzo scale. In addition to the viewpoint of the plural scale, utilizing the mezzo scale is original too. With this analysis, it will be possible to grasp a coordinated image of the Red River Delta by combining the macro image from a statistical approach and the micro image from a detailed field survey. The study area of this paper is the Thanh Mien district, Hai Duong province. This is befitting for a study area for two reasons: first because it is located around the middle of the Red River Delta, and therefore repre- 
sents the delta area, and second because the Thanh Mien district is far from such large cities as Hanoi, and Hai Phong which faces Tonkin Gulf. Therefore, it has less urban or market influences, and hence the village community bonds are relatively tight. In the same way, Pham Tan village was chosen as a study village, because it is one of the most remote villages in the Thanh Mien district. This paper is based on the data of field surveys from 1998 to 2001. I mainly interviewed local officers and farmers of 3 areas of scale (Thanh Mien district, 18 communes in the Thanh Mien district, and villages under commune), and gave a questionnaire to agricultural households in Pham Tan village (322 sets of the questionnaire were collected).

Doi Moi's impact on each rural village is different and in the diversification progresses, which reflects each socio-economic background. This could be shown clearly through the analysis of the mezzo scale (district level), and it can be said that the traditional autonomy or social bands are continuously reproduced under the Doi Moi period. The difference develops not only at the village level but also at the farm household level. For instance, within only 8 years after land distribution in 1993, the accumulation of the agricultural land has increased and led to a differentiation of the social stratum. Furthermore, the same has occurred for side economic activities of farmers, especially migrant labor. In short, this diversification can be considered as the economic feature of the Red River Delta and as the result of the decision-making by the farmer who is surrounded by a lot of unstable factors made up of both natural conditions and market tendencies.

The social network plays an important role in both the opportunity and the process of individual economic activity; moreover, active applications emerge such as forming labor groups and chain migration. The social network on the Red River Delta is characterized by "face to face" relations. Therefore, it is possible to say that the social network in Vietnam is a personal network formed in the life stage of the individual, and that it is always reproduced by practical economic activity or economic art.

The development of this social network is the fundamental problem concerning the social essence on the Red River Delta. Moreover, clarifying the personal network will contribute to the examination of the basic characteristics of Vietnamese society that is important not only for rural society but also for urban society.

The economic development brought by Doi Moi activates the economic activity and activates the social network which links an individual to an individual, and it shows the tendency to create expansion beyond the old network based on the village society. This movement is considered to be one of main factors that brings about social dynamism.

Keywords : rural society, Doi Moi, social network, diversified farming, migrant labor, the Red River Delta 